\title{
DDX41 Gene Mutation
}

National Cancer Institute

\section{Source}

National Cancer Institute. DDX41 Gene Mutation. NCI Thesaurus. Code C151900.

A change in the nucleotide sequence of the DDX41 gene. 